\title{
LABOUR LAW AND CIVIL LAW LIABILITY FOR STRIKE AND/OR OTHER INDUSTRIAL ACTION
}

\begin{abstract}
In Polish labour law system both employees and unions are responsible for conducting an illegal strike or other protest action.Various liability regimes apply in those situation: tort, contractual and employee-based. In practice, it results in various problems and rationally unjustified differentiation of the type of responsibility for participation in illegal collective action.
\end{abstract}

Słowa kluczowe: strajk, „inna” akcja protestacyjna, odpowiedzialność cywilna, prawo pracy, spór zbiorowy Key words: strike, other industrial action, civil liability, labour law, labour disputes

\section{Introduction}

The intrinsic characteristics of any collective industrial action ${ }^{1}$ in labour relations are various negative consequences, ${ }^{2}$ both for the employer and for the society. They occur as a result of use by the collective of workers of economic and/or organizational coercion towards the employer and persons acting on his behalf. A dysfunction of the social environment that arises as a result of this type of action generates the problem of legal liability ${ }^{3}$ of the parties acting on the employees' side, especially when the strike or other industrial action is illegal.

1 See: K.W. Baran, "Inne" niż strajk akcje protestacyjne w systemie polskiego prawa pracy [Industrial actions "other" than strike in the Polish labour law system], in: Stosunki zatrudnienia $w$ dwudziestoleciu społecznej gospodarki rynkowej. Księga pamiątkowa z okazji jubileuszu 40-lecia pracy naukowej Profesor Barbary Wagner [Employment relations in the twenty years of social market economy. Memorial book for the 40th anniversary of academic work of Professor Barbara Wagner], A. Sobczyk (ed.), Warszawa 2010, p. $121-123$

2 See: T. Kotarbiński, Wybór pism [Selected writings], Warszawa 1957, p. 33.

3 See: W. Sanetra, Odpowiedzialność według prawa pracy. Pojęcie, zakres, dyferencja [Liability under labour law. The concept, the scope, the differentiation], Wrocław 1991, passim. 
The concept of legal liability has various meanings in the legal system. ${ }^{4}$ Without going into detailed distinction, ${ }^{5}$ for the purposes of this study, in the material context I will refer to a broad scope which relates to all negative consequences arising in the normative sphere. ${ }^{6}$ At this point, it is worth emphasizing that they will not be limited only to legal sanctions secured by state coercion. Such approach to the problem will allow for its comprehensive presentation.

The normative sources of liability for strike and other industrial action are strongly diversified. In my opinion, de lege lata, on the basis of this criterion, it is reasonable to distinguish three basic levels, namely labour, civil and criminal law level. In this study, I will focus on the first two levels. They have common characteristics, since they both have material and personal character in the current legal system. It is worth emphasizing that they encroach upon each other. Hence the argument on the diffusion of labour law liability and civil law liability for strike and other industrial action seems justified. Many times the provisions of the Labour Code and the Civil Code apply to the same categories of entities.

Before I go into further analysis of the issues directly related to this topic, I should first present the differences between a strike and other industrial action (protest).

The essence of a strike is that employees abstain from work without readiness to perform it, while all protests undertaken by the workers' community without interruption of work or outside the normative working hours have the status of "other" industrial action. ${ }^{7}$ Such interpretation is rooted in the normative provisions of both the Constitution $^{8}$ (article 59 (3) of the Constitution of the Republic of Poland) and ordinary legislation (articles 19 and 25-26 of the act on trade unions). In this context, it is worth emphasizing that the indicated types of non-irenic methods of protest in the practice of industrial relations are strictly connected. They often even interrelate. Strikes are usually accompanied by other protests, sometimes even preceding strike action. De lege lata,

4 See: R. Tokarczyk, Filozofia prawa [Philosophy of law], Lublin 2000, p. 277 ff., L.L. Fuler, Anatomia prawa [Anatomy of law], Lublin 1993, p. $38 \mathrm{ff}$.

5 W. Sadurski, Teoria sprawiedliwości. Podstawowe zagadnienia [A theory of justice. Basic concepts], Warszawa 1988, p. $251 \mathrm{ff}$.

6 See: W. Sanetra, Odpowiedzialność..., p. 8 ff., Z. Kubot, Charakter prawny odpowiedzialności porzadkowej $w$ Kodeksie pracy [Liability for breach of workplace order, policies or procedures under the Labour Code], Państwo i Prawo 1975, 7, passim; M. Sadowski, Wybrane zagadnienia pracowniczej odpowiedzialności materialnej $i$ osobistej [Selected issues relating to financial and personal liability of an employee], Studia z Zakresu Prawa Pracy i Polityki Społecznej, A. Świątkowski (ed.), Kraków 1994, 71, pp. 89-90.

7 B. Cudowski, Pozastrajkowe środki prowadzenia sporów zbiorowych [Non-strike methods of resolution of collective disputes], Monitor Prawa Pracy 2009, 4, p. 173 ff.; K.W. Baran, „Inne” niz strajk akcje protestacyjne w systemie polskiego prawa pracy, p. 121 ff., K.W. Baran, D. Książek, in: Zbiorowe prawo pracy. Komentarz [Collective labour law. Commentary], K.W. Baran (ed.), Warszawa 2016, p. 418 ff.

8 See: K.W. Baran, D. Książek, in: Zbiorowe prawo pracy. Komentarz, p. 2 ff.; L. Florek, Konstytucyjne aspekty wolności związkowych [Constitutional aspects of the freedom of association], Przegląd Sejmowy 2001, 6, p. 16 ff. 
both of these methods remained. In principle, the law does not provide for significant differences in this regard. For this reason, they will be discussed jointly in this study.

It is worth emphasizing that labour law and civil law liability can occur both when the strike and other industrial action were legal and when they were illegal. Many times the same behaviour of persons on strike and other protesters, regardless of the formal status of the industrial action itself, updates and determines the regime of liability. Of course, in the practice of industrial relations, the liability applies usually when the workers' collective undertakes illegal forms of protest. ${ }^{9}$ At this point, it should be noted that the concept of illegal strike is not known in the system of collective labour law. The same applies to other industrial action. However, the provisions of article 26 (3) of the act on resolution of labour disputes use the concept of strike or other industrial action organized contrary to the provisions of the act.

In this context, particularly important is the interpretation of the expression "contrary to the provisions of the act" used in article 26 (3) of the act on resolution of labour disputes. Certain doubts arise as to whether it refers only to the act on resolution of labour disputes and violation of its provisions, or to any law regulating the course of a strike and/or other industrial action. The literal interpretation of this provision seems to speak for the first of the indicated options. However, I think that the second option is correct. I believe, also by reference to axiological dimension, that in the rule of law, entities operating in industrial relations should, within collective disputes, respect all statutory provisions, regardless of the act in which they are included.

In analyzing the provisions of article 26 (3) of the act on resolution of labour disputes, it is worth pointing out the levels in which the organization of a strike ${ }^{10}$ and/or other industrial action may lead to violation of statutory provisions. They are: material (article 1 , article 4 (1), article 10, article 17 (1), article 19 (1), article 25 (1)), personal (article 2, article 18, article 19 (2) and (3)), temporal (article 4 (2), article 7, article 12, article 22), functional (article 17 (2) and (3), article 20, article 21). ${ }^{11}$

The above list is not exhaustive. Because of the diversity and dynamics of industrial actions in industrial relations, indication of all possible violations of law does not seem possible. It is worth emphasizing, however, that the above remarks relate not only to "ordinary" protest and strike actions, but also to those of a solidarity nature. For example, as regards collective disputes, an illegal strike is a substitute solidarity strike undertaken in the interest of employees who, for one reason or another, do not exercise their right to strike. Also in the case of warning strikes, violation of the provisions determining the rules of organization of strikes (e.g. temporal) triggers labour law or civil law liability.

9 See: B. Cudowski, Odpowiedzialność prawna uczestników nielegalnego strajku [Legal liability of the participants in illegal strike], Praca i Zabezpieczenie Społeczne 1996, 2, p. 48-55 and Praca i Zabezpieczenie Społeczne 1996, 3, p. 55-60.

10 See: P. Korus, Strajk nielegalny [Illegal strike], Studia z Zakresu Prawa Pracy i Polityki Społecznej 1997, 1, p. $145 \mathrm{ff}$.

${ }^{11}$ K.W. Baran, Zbiorowe prawo pracy. Komentarz, Warszawa 2010, passim. 
The type and scope of liability is differentiated depending on the status of the person participating in the industrial action and the role of such person. In the normative and functional perspective, three basic categories of entities can be distinguished, namely: an organizer ${ }^{12}$ a leader ${ }^{13}$ and a passive participant. ${ }^{14}$ The first one is the entity undertaking preparatory activities to start a strike and/or other industrial action. On the other hand, a leader is the person who actually decides about its course. A passive participant is a person who is neither an organizer nor a leader, and therefore only participates in a protest. Of course, this does not mean that his behaviour should be solely passive.

When analyzing the personal dimension of liability for organizing a strike and/ or other industrial action, it should be emphasized that employees or other persons participating in it may perform various roles. For example, it should be pointed out that the organizer of a strike does not have to be its leader, and the leader is not necessarily its organizer. For this reason, organizers are not responsible for the misconduct that occurred during the strike, if they are not leaders of such strike.

\section{Labour law liability for strike and/or other industrial action}

In personal terms, the scope of labour law liability for strike and/or other industrial action applies only to persons who enjoy the employee status. It does not matter whether they provide work under a contractual or non-contractual employment relationship and whether it is conventional or unusual. However, these regulations do not apply to other categories of persons in non-labour law employment. In such case the provisions of separate laws governing employment of specific categories of public sector employees (pragmatyki) or general civil-law provisions will apply.

De lege lata, the material dimension of labour law liability for a strike and/or other industrial action is strongly diversified. According to a general formula, such liability may be personal and/or financial. At the same time, it is worth emphasizing that each of these legal regimes can be applied separately to the employee, but the sanctions may also be accumulated. The division adopted for the purposes of this study is a model and serves delimitation purposes on a general theoretical level. In the practice of industrial relations, many times the application of one sanction entails indirectly other negative consequences. An example may be the imposition on an employee, who participates passively in other illegal industrial action, of a penalty for breach of workplace order, policies and procedures (so called kara porzadkowa), which results in depriving him of

12 See in particular: A. Chabrowska, Odpowiedzialność pracownika za zorganizowanie i udział $w$ nielegalnym strajku [Liability of an employee for organising and participation in an illegal strike], in: Z problematyki prawa pracy i polityki socjalnej, A. Nowak (ed.), Katowice 1994, 11, p. 39; W. Masewicz, Zatarg zbiorowy pracy [Collective dispute], Bydgoszcz 1994, p. 186-188; P. Korus, Strajk..., p. 166-167.

13 See: B. Wagner, Odpowiedzialność za zorganizowanie i udział w nielegalnym strajku [Liability for organising of and participation in an illegal strike], Praca i Zabezpieczenie Społeczne 1992, 1, p. 42-43.

14 See: K.W. Baran, Zbiorowe prawo pracy [Collective labour law], Kraków 2002, p. 321-323. 
monetary benefits (e.g. bonuses) in the financial sphere. This means that the employee's liability is usually heterogeneous, even if only one sanction is applied by the employer.

When discussing the problem of employee's liability for participation in a strike and/or other industrial action, the concept of sanctions in a broad sense covers the declarations of will of the employer leading to termination of an employment relationship. According to textual interpretation of article 23 (1) of the act on resolution of labour disputes, employee's participation in a strike organized in accordance with the provisions of the act does not constitute a breach of employee's duties. Ab exemplo, in my opinion this mechanism is applicable to an industrial action other than a strike. At this point, it should be emphasized that this provision does not establish a general employee's immunity in the legal collective actions, because on general terms, the employee is liable for all kinds of torts which meet the conditions provided for in article 52 of the Labour Code, and even in article 45 of the Labour Code.

On the other hand, from the a contrario argument applied to the directive formulated in article 23 (1) of the act on resolution of labour disputes it can be concluded that the employee's participation in a strike organized contrary to the provisions of the act constitutes violation of employee's duties. In my opinion, based on a simili argument, it is permissible to extend it to other industrial actions. This kind of interpretation is justified by the eiusdem generis principle.

The very fact of employee's participation in a strike and/or an action organized contrary to law does not have to mean that he violated his basic duties ${ }^{15}$. Under the regulations applicable in the system of labour law, a necessary element is the existence of fault ${ }^{16}$ on the part of the employee. Participants in all types of industrial actions, both legal and illegal, are subject to general rules, ${ }^{17}$ allowing the employee to be held liable only for the culpable act or omission. Moreover, it is the type and degree of fault that decisively determines the scope of liability. The case-law of the Supreme Court also goes in this direction. ${ }^{18}$ It provides that the mere fact of organizing and participating in an illegal strike determines the existence of a serious violation of employee's duties by the employee organizing the strike.

In personal terms, the "sanction" for actions or omissions in an industrial action which seems to be most "severe" for an employee is termination of the employment relationship under article $52 \$ 1$ (1) or (2) of the Labour Code. ${ }^{19}$ The basic premise

15 See a judgment of the Supreme Court of 17 July 2009, I PK 45/09, argument 1, Lex 607245.

16 See: W. Sanetra, Wina jako przyczyna niezwłocznego rozwiązania umowy o pracę przez zakład pracy [Fault as a cause of immediate termination of a contract of employment by the employer], Ruch Prawniczy, Ekonomiczny i Socjologiczny 1972, 2, p. 65 ff.

17 See: K.W. Baran, in: Kodeks pracy. Komentarz [The Labour Law. Commentary], Warszawa 2012, p. 357-358 and the case-law referenced there.

18 See a judgment of the Supreme Court of 7 February 2007, I PK 209/06, (OSNP 2008, no. 5-6, item 65).

19 See: A. Sobczyk, Rozwiazanie umowy o prace bez wypowiedzenia [Termination of a contract of employment without notice], Gdańsk 2010, p. $15 \mathrm{ff}$. and the literature referenced there 
that authorizes an employer to make such a declaration of will is a gross violation of employee's basic duties ${ }^{20}$ or committing a crime. ${ }^{21}$ In the former case, it usually involves non-compliance with an obligation to perform work (e.g. during a strike) or carrying it out incorrectly (e.g. during the "work-to rule" action), while in the latter case it involves the offences committed during or in connection with the industrial action which prevent further employment of an employee in a given position, if it is obvious ${ }^{22}$ or confirmed by a valid judgment.

According to article $52 \$ 1(1)$ of the Labour Code, the level of employee's liability is significantly affected by his role in the strike. As a rule, passive participation is not sufficient to apply the sanctions provided for in this provision. This liberal approach was extended by the Supreme Court in its judgment of 7 February 2007, I PK 209/06, to include even the organizer and persons leading the illegal strike. ${ }^{23}$ In my opinion, in principle, this does not change the view, well established in the case-law since the beginning of the 1990s, that organizers and leaders of illegal strikes should face more severe liability.

In this regard, an important factor directly affecting the degree of fault is awareness of the illegality of the strike and/or other industrial action. Thus article $52 \$ 1$ (1) of the Labour Code may be applied even to passive participants in a strike, if they were fully aware of the unlawfulness of their conduct and despite the received warnings and calls to abandon further participation in the strike, they continued it. ${ }^{24}$ However, the situation is different in the case of organizers of illegal strike and its leaders. They are required to know the normative rules of carrying out an industrial action. Basically, they should be aware of the unlawfulness of the actions taken. However, there are derogations from this rule, if the lack of awareness of the illegality of the strike was caused by special circumstances beyond their control. ${ }^{25}$

According to the a fortiori argumentation (and more specifically - a maiori ad minus argument), the fact that in the case of a specific strike and/or other industrial action, there occurred circumstances justifying the application of article $52 \S 1$ (1) of the Labour Code, does not mean that the employer cannot terminate a contract of

20 See: A. Wypych-Żywicka, Klauzule określające przesłanki dopuszczalności rozwiązania umów o pracę [Clauses laying down the conditions for termination of contracts of employment], in: Studia z Zakresu Prawa Pracy i Polityki Społecznej. Liber Amicorum prof. dr hab. Andrzej Marian Świątkowski, L. Mitrus (ed.), Kraków 2009, p. 626.

21 See: E. Baran, K.W. Baran, Przestępstwo jako podstawa rozwiązania stosunku pracy [Offence as a basis for termination of an employment relationship], Prawo Pracy 2001, 7-8, p. 36-37.

22 See for example: K.W. Baran, in: Kodeks pracy. Komentarz, p. 372-373.

23 See: Z. Hajn, Strajk w orzecznictwie Sadu Najwyższego [Strike in the case-law of the Supreme Court of Poland], in: Księga pamiątkowa w piątą rocznicę śmierci Profesora Andrzeja Kijowskiego, Z. Niedbała (ed.), Warszawa 2010, p. 67-73.

24 See a judgment of the Supreme Court of 18 March 1992, I PRN 11/92, Lex 12697, a judgment of 17 February 2005, II PK 217/04, OSNP 2006 no. 13-14, item 209.

25 See a judgment of the Supreme Court of 27 November 1997, I PKN 393/97, OSNP 1998, no. 17, item 511 . 
employment with an employee who passively or proactively participated in the protest. The employer's right to terminate the contract without notice through the fault of the employee is in fact the employer's right which the employer does not have to exercise. At this point it is worth noting that the causes justifying the immediate termination of a contract of employment through the fault of the employee constitute also a legitimate $e^{26}$ cause of termination of the contract upon notice. ${ }^{27}$ Therefore, also a notice of termination of employment may be a manifestation of the employee's personal liability for his participation in an illegal protest.

The material scope of this category of liability is significantly broader than the one provided for in article $52 \$ 1$ (1) and (2) of the Labour Code. This is due to the fact that because of the open catalogue of circumstances justifying the termination of a contract of employment as a consequence of the employee's participation in a collective protest, the number of such circumstances is far greater than this specified in the indicated provision. Therefore, the cause of dismissal of an employee may be the participation alone - even passive - in an illegal industrial action, if the employee was aware of its illegality, even if the employer did not inform him about it.

Any behaviour of the employee during the industrial action, also outside the workplace, may result in termination if, as a consequence, the employer lost confidence in such employee. By this I mean in particular all activities that defame the employer or persons acting on his behalf, both in internal relations and outside of the company structures. In the first case, this refers in particular to the failure to take due care of the employer's property, while in the second case it is usually about the image and media presence of the employer. When illustrating this last situation, it can be argued that termination would be justified if an employee presented his employer or relations in the workplace in the social media in a wrongly negative way. Refusal to comply with the employer's instructions during a strike and/or other industrial action may also be the cause justifying termination of the contract of employment upon notice, provided that the omission infringes the statutory rules of participation in the strike (e.g. article 21 (2) of the act on resolution of labour disputes). ${ }^{28}$

Listing all the causes justifying the dismissal for actions or omissions of the employee during legal or illegal protest de lege lata is not possible. This is due to the fact that article $45 \$ 1$ of the Labour Code is an open general clause that refers many times to non-legal norms and assessments.

26 See more: A. Wypych-Żywicka, Zasadność wypowiedzenia umowy o pracę [Legitimate termination of a contract of employment], Gdańsk 1996, passim.

27 See: K.W. Baran, Zbiorowe prawo pracy [Collective labour law], Warszawa 2002, p. 324; J. Piątkowski, Prawo stosunku pracy w teorii i praktyce [Employment relationship law in theory and in practice], Toruń 2006, p. $428 \mathrm{ff}$.

28 See: J. Piątkowski, Uprawnienia zakładowej organizacji związkowej [Rights of a company trade union organisation], Toruń 2014 p. 291. 
Employee's behaviour during a collective protest may also have negative consequences ${ }^{29}$ for him in terms of change of the terms and conditions of employment under article 42 $\$ 1-3$ of the Labour Code. This may be the case in particular when the employer gives a notice of change to wage or working conditions (e.g. reduction of remuneration, change of the job position). This can be motivated by the employer's conviction of the necessity to restructure the workplace as a result of the strike and/or other industrial action. In this case, the employee's liability may be both personal and financial.

The classic example of heterogeneous liability for a strike and/or other industrial action is liability for breach of workplace order, policies or procedures. ${ }^{30}$ Depending on the sanction ${ }^{31}$ imposed by the employer, it may be either personal or financial.

The first situation occurs when an employee, during a collective protest, fails to comply with the work order, OHS regulations and fire safety regulations adopted in the workplace. $^{32}$ As a result, the employer is entitled to impose a non-pecuniary penalty in the form of a warning or a reprimand. ${ }^{33}$

On the other hand, financial liability in the form of a pecuniary penalty may be imposed on an employee in the event of non-compliance with OHS and fire safety regulations, leaving the place of work without an excuse (e.g. during an absenteeism strike). The list of infringements included in article $108 \$ 2$ of the Labour Code is exhaustive, therefore, according to exceptiones non sunt excendendae formula, it cannot be interpreted extensively to situations which are not explicitly stipulated in this provision. This applies also to all circumstances occurring during a legal or illegal strike and/or other industrial action. Therefore, for example, a pecuniary penalty cannot be imposed on the employee for intentional damage to his employer's property.

Financial liability is also the employee's liability for damage caused to the employer. In the case of a strike and/or other industrial action, the general provisions of articles 114-122 of the Labour Code will apply. ${ }^{34}$ This means a significant level of differentiation as regards the amount of liability, depending on whether the damage was caused deliberately or unintentionally. It does not matter if the protest was legal or not. The employee may also be financially liable for damage caused during a legal protest if the conditions provided for in article 114 or 122 of the Labour Code were met. It is obvious

29 See: P. Wąż, in: Komentarz do Kodeksu pracy [A commentary on the Labour Code], K. Walczak (ed.), Warszawa 2012, p. 161-162.

30 Z. Góral, Pracownicza odpowiedzialność porządkowa [Liability of a worker for breach of workplace order, policies or procedures], Łódź 1987, passim; Z. Kubot, Charakter prawny odpowiedzialności porządkowej w kodeksie pracy, p. 85 ff.; W. Patulski, O pracowniczej odpowiedzialności porządkowej, in: Jedność w różnorodności. Studia z zakresu prawa pracy, zabezpieczenia społecznego i polityki społecznej. Księga pamiątkowa dedykowana Profesorowi Wojciechowi Muszalskiemu, Warszawa 2009, p. $141 \mathrm{ff}$.

31 B. Patulski, W. Patulski, Odpowiedzialność porządkowa, Gdańsk 2000, passim.

32 See: W. Perdeus, in: Kodeks pracy. Komentarz, K.W. Baran (ed.), Warszawa 2016, p. 777 ff.

33 W. Masewicz, Kary porządkowe jako szczególny środek dyscyplinujący [Penalties for breach of workplace order, policies or procedures as a specific disciplinary measure], Państwo i Prawo 1979, 3, p. 75 ff.

34 See for example: M. Piekarski, Pracownicza odpowiedzialność odszkodowawcza [Employee's liability for damages], Warszawa 1976, passim. 
that in the practice of industrial relations the threat of causing harm to the employer will arise in the case of organization of an illegal strike. It is worth emphasizing that regardless of the employee's role in a strike, the employee may be liable up to the full amount of damage if it was caused with a direct intent (dolus directus) or even a conditional intent (dolus eventualis). Such interpretation is justified by the lege non distinquente argument applied to article 122 of the Labour Code.

As a rule, damage to the employer's property during a strike and/or other industrial action is not caused by an individual employee. They usually act together in a variety of roles and personal configurations. Therefore, in a situation where damage is caused jointly by several employees or an employee together with another person or persons employed for example under non-labour law employment relationships, joint and several liability should be assumed on the basis of a completudine argument (article 366 of the Civil Code in connection with article 300 of the Labour Code). However, when some of the perpetrators acted unintentionally and others acted deliberately, then liability based on in solidum formula should apply, which essentially is divided and depends on the nature and degree of fault.

In a broad sense, the negative consequence of employee's participation in a strike is deprivation of remuneration. This happens regardless of whether the strike was legal or not. As far as the first category is concerned, it follows explicitly from the provisions of article 23 (2) of the act on resolution of labour disputes. On the other hand, when it comes to illegal strike, this is justified by a fortiori argument. Since no remuneration is paid for the time of participation in a legal strike, all the more it will not be paid for the time of participation in an illegal strike. In the axiological dimension, this regulation is rooted in the reciprocity of an employment relationship.

De lege lata, a more serious issue is payment of remuneration for participation in other industrial action. This has not been explicitly regulated in the current legal system. In my opinion, it is necessary to follow the rule according to which, if it is illegal, the directive laid down in article 23 (2) of the act on resolution of labour disputes should apply. Such approach introduces an appropriate level of inter-system correlation, which corresponds with a coherentia argumentation. On the other hand, account should be taken of the fact that other industrial actions may occur in industrial relations (e.g. obstructionism, work-to-rule), during which work is performed only to a limited extent. In my opinion, in such case the principle of proportionality should apply, and remuneration should be paid in the amount which takes into account the quantity and quality of the work performed during such other industrial action. The proposed interpretation has its textual justification in the general standards provided for in article $78 \$ 1$ in fine of the Labour Code..$^{35}$ It guarantees an appropriate level of effectiveness of the provisions of collective labour law, which is in compliance with ut res valeat quam pereat principle.

${ }_{35}$ See: M. Skąpski, in: Kodeks pracy. Komentarz [The Labour Code. Commentary], K.W. Baran (ed.), Warszawa 2012, p. $563 \mathrm{ff}$. 
When analyzing the problem of employee's liability for participation in a strike and/ or other industrial action, worth mentioning is also disciplinary liability. ${ }^{36}$ Its personal scope covers the employees of administration who provide work on the basis of separate laws governing employment of specific categories of public sector employees (so called pragmatyki urzędnicze) ${ }^{37}$ Because of the prohibition established in article 19 (3) of the act on resolution of labour disputes, participation in a strike, ${ }^{38}$ regardless of the role of the employee in it, is always a disciplinary tort ${ }^{39}$. In this respect, the rules of liability ${ }^{40}$ provided for in the separate laws governing employment of specific categories of public sector employees (pragmatyki) apply. In the system of Polish labour law, they have a particular character, but this does not change the fact that the rules and procedures are based on identical values.

De lege lata, more diversified is the issue of disciplinary liability of employees for organizing and participating in other industrial action. If it is dysfunctional, the participation in such action may be classified as a culpable breach of official duties, or even violation of dignity of service or profession and sanctioned by disciplinary penalties according to the catalogue defined in the separate laws (pragmatyki).

To sum up the deliberations on the employees' liability for participation in a strike and/ or other industrial action, it is worth emphasizing that in the current Polish labour law system it is strongly diversified. It has both personal and financial dimension. Moreover, sanctions are often heterogeneous because they affect both the personal and property status. In addition, in some situations their cumulative use is allowed. Such regulations do not raise any doubts in the case of illegal forms of protest, but they may turn out to be unfair if they are applied to participants of legal collective actions.

\section{Civil law liability for strike and/or other industrial action}

A starting point for the deliberations on the civil law liability for a strike and/or other industrial action will be the conclusion that in the Polish labour law system there exists a dualism of liability regimes. In addition to the labour law liability regime governed primarily by the provisions of Labour Code, there are also civil-law regulations based

36 See in particular: T. Kuczyński, in: T. Kuczyński, E. Mazurczak-Jasińska, J. Stelina, System prawa administracyjnego. Stosunek stużbowy [The system of administrative law. Service relationship], R. Hauser, Z. Niewiadomski, Z. Wróbel (ed.), Warszawa 2011, p. 444 ff.; idem, Przesłanki odpowiedzialności dyscyplinarnej pracowników [Premises of disciplinary liability of employees], Państwo i Prawo 2003, 9.

${ }_{37}$ See for example the act of 21 November 2008 on civil service (ustawa o służbie cywilnej), Journal of Laws [Dz. U.] no. 227, item 1505 as amended; the act of 16 September 1982 on the employees of public offices (ustawa o pracownikach urzędów państwowych), Journal of Laws [Dz. U.] no. 86, item 953 as amended.

38 K.W. Baran, Zbiorowe prawo pracy. Komentarz, p. 454-455.

39 See for example article 78 (3) of the act on civil service

40 See: T. Kuczyński, in: T. Kuczyński, E. Mazurczak-Jasińska, J. Stelina, System prawa..., p. 448 ff. 
on the provisions of the Civil Code. It is worth emphasizing that there is a specific diffusion between them, due to the penetration of the provisions of Civil Code into the labour law system.

When analyzing the civil law liability for a strike and/or other industrial action, it should be emphasized that it may be liability both in tort and liability arising from non-compliance with obligations. In the practice of industrial relations, the former category seems to dominate, ${ }^{41}$ because a strike and/or other industrial action organized contrary to the provisions of the act, because of its illegality, gives rise to organizer's liability in tort. In terms of article 415 of the Civil Code, it is a tort. However, in the Polish legislative system, an organizer may also be contractually liable in the situation when trade unions in a collective agreement or other collective arrangement waived the right to protest, and despite such waiver they nevertheless started it. Failure to comply with the obligation, assumed in the collective agreement, not to carry out a strike and/ or other industrial action, gives rise to the liability of the trade union being a signatory to the agreement for the damage caused, in accordance with the principles set out in article 471 et seq. of the Civil Code.

When addressing the problem of tort liability for a strike and/or other industrial action undertaken contrary to the provisions of the act, it is worth considering its personal scope. The starting point will be an argument that claims in respect of such protest commenced in the workplace can be raised by any party who suffered damage as a result of it. This applies not only to employer(s) against whom the strike and/or industrial action is specifically directed, but also to third parties who have been harmed in consequence or on the occasion of conducting it. Therefore, they can also be other entrepreneurs, public authorities and even natural persons who have been harmed as a result of illegal protest (e.g. passengers, road users or consumers).

Article 415 of the Civil Code sets out a general liability for all torts, without any differentiation. On the other hand, according to article 26 (3) of the act on resolution of labour disputes, liability for a strike and/or other industrial action is limited to the organizer. Therefore, a question arises about the relationship between both of these provisions. In particular, the question is whether liability under the civil law applies only to the organizer of an illegal strike and/or other industrial action or also to other entities who commit a tort during such action. There are two possible interpretations. The first one, according to which article 26 (4) of the act on resolution of labour disputes is a special provision in terms of its consequences, it eliminates the liability of other entities, and the second one, according to which this provision as reference provision indicates only the sources of liability in relation to one category of entities. I am in favour of the second interpretation. First and foremost, systemic reasons speak for it. Specifically, I mean the prohibition of interpreting legal norms that would result in a legal loophole. If the first of the presented options was adopted, there would be an objective legal loophole with

${ }^{41}$ A. Marek, Spory zbiorowe. Część III. Prawo do strajku [Collective disputes. Part III. The right to strike], Służba Pracownicza 2009, 3, p. 24-25. 
respect to persons other than the organizers of an illegal strike and/or other industrial action, because it would not be clear on what terms they bear civil liability. In the light of the constitutional directive of equality, it would be unacceptable to interpret that they do not bear any liability for damage caused as a result of an industrial action organized contrary to law.

Article 26 (3) of the act on resolution of labour disputes is a first degree reference norm. It does not specify how the civil law provisions apply to the liability for a strike or/and other industrial action. This provision is not comprehensive and defines only in fragments, in the personal scope, the issue of civil liability for a strike and/or other industrial action organized contrary to the provisions of the act. This means than parties other than the organizers may de lege lata also be held liable.

Continuing the deliberations on the personal aspect of civil liability, attention should be given to an organizer of an illegal strike and/or protest. The organizer may be both a legal person (e.g. trade union) and a natural person. In the latter case, it does not matter if he belongs to a trade union or even if he is an employee. Civil liability may be imposed also on persons who do not have the status of an employee, such as persons employed under civil-law contracts (contractors), self-employed or volunteers. Moreover, this liability applies also to persons who are not at all employed by the employer (e.g. former employees) and organized an illegal industrial action.

According to article 26 (3) of the act on resolution of labour disputes, the organizer is a party who undertakes preparatory activities and defines the rules for the conduct of the strike and/or other industrial action. In practice, both logistic and implementation activities are in question. The literal wording of article 26 (3) limits the civil liability to the implementation stage, because it uses the phrase "organized". This does not mean, however, that de lege lata such liability is waived in respect of the earlier stages of the industrial action. In such case, general principles defined by the provisions of the Civil Code will apply.

In this context, a problem of civil liability of parties other than the organizer arises. This refers primarily to persons leading the strike and/or other industrial action contrary to the provisions of the act. In practice, such situation may arise if the control over the course of such action is taken over from the organizer (e.g. trade union board) by an informal group of employees (e.g. self-appointed protest committee). If it makes decisions that violate the law and at the same time cause damage, then such persons, if they do not have the status of employees, are obliged to repair the damage in accordance with general principles laid down in the Civil Code. The same applies if the damage is caused by persons participating in an illegal industrial action in a role other than the organizer or leader. However, this does not apply to damage caused by employees who are not the organizers of an illegal strike and/or protest. In this regard, two regimes of liability collide in the Polish legal system: civil-law liability and labour-law liability (articles 114-122 of the Labour Code). In my opinion, in the event of such a collision, the norms of the Labour Code, as lex specialis, should prevail. This means that the employee is fully liable for the damage only if caused by intentional fault. In practice, this can happen 
when an employee, leading an illegal strike or other industrial action or participating in it, failed to comply with his duties, acting with a direct (dolus directus) or conditional (dolus eventualis) intent to cause damage ${ }^{42}$ (e.g. refused to secure the goods belonging to the employer, which then have been destroyed).

According to article 422 of the Civil Code, financial liability for damage caused by a strike and/or other industrial action organized contrary the provisions of the act is borne not only by the entity causing the damage directly, but also by an instigator and an accessory. In the practice of industrial relations it could be an advisor of a trade union who encourages the union's statutory authorities to violate the legal order (for example, to refrain from conducting a referendum). According to article 441 of the Civil Code, liability of these persons is joint and several with the perpetrator. Moreover, in exceptional cases, pursuant to article 422 of the Civil Code, the financial liability can be borne even by a competitor of the employer at whose site the illegal collective action was organized, if he took up activities to trigger such action, and then consciously benefited from the damage caused (e.g. by introducing his products into the market segment occupied by the employer affected by the illegal strike).

When analyzing the issue of civil liability for illegal strike and/or other industrial action, worth considering is the status of a trade union as its organizer. A respective decision is usually made by its governing bodies (e.g. management board). De lege lata, there is no doubt that article 416 of the Civil Code will apply in this regard. This provision states that a legal person is obliged to repair damage caused through the fault of its governing body. In the system of Polish labour law, trade unions acquire, as of the date of registration, legal personality. In the context of this provision a question arises whether the directive formulated in it applies to all the bodies of a trade union or only to its statutory bodies. In my opinion, based on lege non distinquente argument, it applies to all bodies, including those which are not regulated by the statute but by other internal acts of the union (internal rules).

More serious doubts arise in a situation where a strike and/or other industrial action contrary to the provisions of the act is organized by a committee made up of representatives of various trade union organizations and non-unionized workers. In my opinion, in such case the financial liability should be governed by the provisions of article 441 of the Civil Code. In practice, this means that the harmed employer or other entity will be able to claim all or part of the compensation from all participants of this body jointly, or from several of them or from each of them individually. In such case, the mechanisms of joint and several liability ${ }^{43}$ laid down in article 366 of the Civil Code ${ }^{44}$ will apply. In the axiological dimension, it is based on the assumption that each of the accomplices who

${ }^{42}$ See for example: B. Wagner, in: Kodeks pracy. Komentarz [The Labour Code. Commentary], B. Wagner (ed.), Gdańsk 2010, p. 633. ff.

${ }_{43}$ B. Lewaszkiewicz-Petrykowska, Konstrukcja solidarności biernej w Kodeksie Cywilnym [The concept of passive joint and several liability in the Civil Code], Studia Prawno-Ekonomiczne 2003, p. 16 ff.

${ }_{44}$ See: W. Dubis, in: Kodeks cywilny [The Civil Code. Commentary], E. Gniewek (ed.), Warszawa 2008, p. 595. 
caused damage is liable to the injured party. The mechanism presented here also tones, at least to a small extent, the risk of insolvency of one or several entities organizing the illegal protest.

An issue worth further attention is the material (objective) dimension of liability for the strike and/or other industrial action organized contrary to the provisions of the act. First, it should be decided whether it covers only property damage or also non-property damage. In my opinion the organizer's civil liability covers both of these categories, because the legislation in force does not make any difference on this ground. Such interpretation is also supported by teleological considerations since the illegal protests in the workplace very often involve violation of personal rights of the employer or persons acting on his behalf.

First, I will focus my attention on property damage. The basic problem arising in connection with a strike and/or other industrial action carried out contrary to the provisions of the act is the scope of payable compensation. More specifically - whether it covers the full damage or only the actual loss. The answer to this question is not clear, as there is a significant differentiation in this matter in the current legal system. If the claim is pursued against an employee who is not the organizer of the illegal protest, then the limitation laid down in article 115 of the Labour Code will apply.5 This conclusion is based on a contrario argumentation applied in relation to article 26 (3) of the act on resolution of labour disputes. In the case of entities other than the organizer, who cause the damage intentionally, the principle of full compensation is applicable, under article $361 \S 2$ of the Civil Code ${ }^{46}$ or article 122 of the Labour Code respectively. ${ }^{47}$ This view is supported by a coherentia directive.

A property loss resulting from illegal protest may also occur outside labour relations and involve the property of third parties. By this I mean destruction of or damage to property that occurred as a result of blockade of roads, railroad tracks, waterways, border crossings and occupation of public buildings or picketing (e.g. destruction of a bank facade the owner of which refused to credit an unprofitable business venture). Compensation for losses incurred in the equipment by the police in connection with restoration of public order violated by the illegal assembly of protesting workers may also be claimed from its organizer or direct violators under article 366 in connection with article 415 of the Civil Code.

As regards calculation of the amount of property damage, ${ }^{48}$ more serious doubts arise in relation to the methods of calculation of profits lost as a result of the strike and/or industrial action carried out contrary to the provisions of the act. The problem is that

45 See: B. Wagner, in: Kodeks pracy..., p. $618 \mathrm{ff}$.

46 Por. L. Stecki, Zasada petnej kompensacji szkody. Zagadnienia wybrane [The principle of full compensation for damage. Selected issues], in: Rozprawy z prawa cywilnego. Ksiega pamiatkowa ku czci Witolda Czachórskiego, J. Błeszyński, J. Rajski (ed.), Warszawa 1985, p. 229 ff.

47 See: B. Wagner, in: Kodeks pracy..., p. 633-636.

48 A. Duży, Dyferencyjna metoda ustalania wysokości szkody [A differentiating method of determination of the amount of loss], Państwo i Prawo 1993, 10, p. $55 \mathrm{ff}$. 
lucrum cessans is hypothetical. ${ }^{49}$ In functional terms, it refers to the calculation of the difference between the state of the victim's property existing after the protest and the state that would exist if this illegal labour protest did not occur. In the practice of industrial relations, this is the case when an illegal strike and/or other industrial action prevents the employer from carrying out normal activities and achieving legitimate revenues, and thus causing a reduction in profit. At this point, it is reasonable to emphasize that the loss of business opportunities is not included in the lucrum cessans. The doctrine of civil law $^{50}$ qualifies such a situation as possible damage, which is not subject to compensation under article 361 of the Civil Code.

When analyzing the problem of civil liability for a strike and/or other industrial action undertaken contrary to the provisions of the act, it should be emphasized that it also covers personal injury. ${ }^{51}$ This means that if, due to an illegal employee protest, a bodily injury, harm to health or death has occurred, its organizer is held liable in accordance with the principles laid down in articles 444-448 of the Civil Code. It applies not only to an employer who is a natural person and persons acting on his behalf (e.g. security guards employed under civil law contracts to restore order in the workplace), but also to third parties (e.g. journalists covering the protest action). The indicated civil law regulations are only binding in the alternative in relation to employees performing work or undertaking actions in the employer's interest during an illegal protest, resulting in injury or death, since they can be classified as an accident at work..$^{52} \mathrm{~A}$ similar mechanism applies to officers employed in paramilitary services (e.g. policemen ${ }^{53}$ who have suffered personal injury in connection with the restoration of public order during workers' protests.

The analysis of the problem of liability for illegal strike and/or other industrial action leads to the conclusion that de lege lata personal rights are also protected ${ }^{54}$. In this regard, the regulations laid down in articles 23-24 of the Civil Code will apply. ${ }^{55}$ They refer to

49 W. Czachórski, A. Brzozowski, M. Safian, E. Skowrońska-Bocian, Zobowiązania. Zarys wykładu [Obligations. An outline], Warszawa 2009, p. 89 ff. and the literature referenced there.

$50 \quad$ Ibidem, p. 91.

51 See: J. Matys, Szkoda na osobie - uwagi na tle art. 444 k.k. [A personal injury - remarks in the context of article 444 of the Criminal Code], Monitor Prawniczy 2004, 10, p. $457 \mathrm{ff}$.

52 Article 3 of the act of 30 October 2002 on social security in respect of accidents at work and occupational diseases (Ustawa o ubezpieczeniu społecznym z tytułu wypadków przy pracy i chorób zawodowych) (consolidated text: Journal of Laws Dz.U. of 2009, no. 167, item 1322 as amended).

53 See for example an act of 16 December 1972 on compensation payable in the case of accidents and diseases related to service in the police (ustawa o odszkodowaniach przysługujacych w razie wypadków $i$ chorób pozostajacych w związku ze służba w Policji, Dz. U. No. 53, item 345 as amended).

54 A. Wojcieszke, Katalog dóbr osobistych w świetle przepisów konstytucji i kodeksu cywilnego [A catalogue of personal rights in the light of the provisions of the Constitution and the Civil Code], Gdańskie Studia Prawnicze 2000, 7, p. 659 ff.; P. Granecki, Dobra osobiste w prawie polskim - zagadnienia dóbr osobistych osób prawnych [Personal rights under Polish law - personal rights of legal persons], Przegląd Sądowy 2002, 5, p. 3 ff.

55 These provisions apply to employees (for example those representing the employer in the collective dispute) through article 300 of the Labour Code. 
the situation in which protesters compromise the non-property values of the employer or third parties. In labour relations there is a risk of violation of, in particular:

- honour and dignity (e.g. disseminating false information about an employer or threatening him or showing gestures commonly regarded as offensive);

- personal freedom (e.g. blocking an exit from the workplace);

- inviolability of home (e.g. unacceptable or intrusive pro-strike agitation in the place of residence or stay);

- personal data (e.g. publishing names of employees refusing to participate in the strike on posters or in cyberspace);

- health (e.g. forcing an employee to start a hunger strike);

- privacy (e.g. watching an employee after working hours with the use of the so-called motorcycle patrols of employer's representatives);

- image (e.g. publication in the electronic communication means of photos or videos of persons opposing the protest).

In Poland, violation of personal rights during industrial actions often takes the form of cyberbullying. It is difficult to combat due to media pluralism and difficult identification of perpetrators. Practical experience shows that it is intensified in particular during illegal collective dispute. It is worth emphasizing, however, that in the normative sphere, the violation of personal rights in the electronic or computer communication environments does not exclude liability. In such case, universal protection measures apply. Their catalogue remains open ${ }^{56}$ according to the type of the personal right violated. ${ }^{57}$ As it seems, the fundamental claim here is to cease the behaviour that violates the personal right. In the alternative, the harmed party may claim financial compensation and undertake actions necessary to remove the consequences of the infringement. At this point, it is worth emphasizing that the civil liability mechanisms discussed above apply by analogy to legal strikes and/or other industrial actions. In no case do they constitute a lawful excuse releasing from liability. In such situation for example the rules similar to those applicable in the case of liability for illegal industrial actions should apply.

\section{Summary}

To sum up the deliberations on liability for a strike and/or other industrial action, I must conclude that there are various regimes applicable in the current legislation, ranging from liability in tort, contractual liability, and labour law liability regime. As a consequence, in the normative dimension, they mix together which sometimes results in differentiation that is not rationally justified. It seems that article 26 (3) of the act on

56 See: A. Cisek, in: Kodeks Cywilny. Komentarz [The Civil Code. Commentary], E. Gniewek (ed.), Warszawa 2008, p. 65.

57 J. Jastrzębski, Kilka uwag o naprawieniu szkody niemajątkowej [Remarks on remedying non-property damage], Palestra 2005, 3-4, p. $32 \mathrm{ff}$. 
resolution of labour disputes is of significant importance. In my opinion, this provision plays a destructive role in the legal system, favouring differentiation of the rules of civil liability of entities involved in illegal collective action. If it was repealed, it would contribute to their unification, which in the long term would support a stronger respect for standards of legality in the Polish labour relations.

\section{References}

Baran E., Baran K.W., Przestępstwo jako podstawa rozwiazania stosunku pracy [Offence as a basis for termination of an employment relationship], Prawo Pracy 2001, 7-8.

Baran K.W., Zbiorowe prawo pracy. Komentarz, Warszawa 2010.

Baran K.W., in: Kodeks pracy. Komentarz [The Labour Law. Commentary], Warszawa 2012.

Baran K.W., "Inne" niż strajk akcje protestacyjne w systemie polskiego prawa pracy [Industrial actions "other" than strike in the Polish labour law system], in: Stosunki zatrudnienia $w$ dwudziestoleciu społecznej gospodarki rynkowej. Ksiega pamiątkowa z okazji jubileuszu 40-lecia pracy naukowej Profesor Barbary Wagner [Employment relations in the twenty years of social market economy. Memorial book for the 40th anniversary of academic work of Professor Barbara Wagner], A. Sobczyk (ed.), Warszawa 2010.

Baran K.W., Książek D., in: Zbiorowe prawo pracy. Komentarz [Collective labour law. Commentary], K.W. Baran (ed.), Warszawa 2016.

Chabrowska A., Odpowiedzialność pracownika za zorganizowanie i udział w nielegalnym strajku [Liability of an employee for organising and participation in an illegal strike], in: $Z$ problematyki prawa pracy i polityki socjalnej, A. Nowak (ed.), Katowice 1994, 11.

Cudowski B., Odpowiedzialność prawna uczestników nielegalnego strajku [Legal liability of the participants in illegal strike], Praca i Zabezpieczenie Społeczne 1996, 2.

Cudowski B., Pozastrajkowe środki prowadzenia sporów zbiorowych [Non-strike methods of resolution of collective disputes], Monitor Prawa Pracy 2009, 4.

Czachórski W., Brzozowski A., Safian M., Skowrońska-Bocian E., Zobowiązania. Zarys wykładu [Obligations. An outline], Warszawa 2009.

Dubis W., in: Kodeks cywilny [The Civil Code. Commentary], E. Gniewek (ed.), Warszawa 2008.

Duży A., Dyferencyjna metoda ustalania wysokości szkody [A differentiating method of determination of the amount of loss], Państwo i Prawo 1993, 10.

Florek L., Konstytucyjne aspekty wolności zwiazkowych [Constitutional aspects of the freedom of association], Przegląd Sejmowy 2001.

Góral Z., Pracownicza odpowiedzialność porzadkowa [Liability of a worker for breach of workplace order, policies or procedures], Łódź 1987.

Granecki P., Dobra osobiste w prawie polskim - zagadnienia dóbr osobistych osób prawnych [Personal rights under Polish law - personal rights of legal persons], Przegląd Sądowy 2002, 5. Hajn Z., Strajk w orzecznictwie Sadu Najwyższego [Strike in the case-law of the Supreme Court of Poland], in: Ksiegga pamiątkowa w piątą rocznicę śmierci Profesora Andrzeja Kijowskiego, Z. Niedbała (ed.), Warszawa 2010. 
Jastrzębski J., Kilka uwag o naprawieniu szkody niemajątkowej [Remarks on remedying non-property damage], Palestra 2005, 3-4.

Korus P., Strajk nielegalny [Illegal strike], Studia z Zakresu Prawa Pracy i Polityki Społecznej 1997, 1.

Kotarbiński T., Wybór pism [Selected writings], Warszawa 1957.

Kuczyński T., in: T. Kuczyński, E. Mazurczak-Jasińska, J. Stelina, System prawa administracyjnego. Stosunek stużbowy [The system of administrative law. Service relationship], R. Hauser, Z. Niewiadomski, Z. Wróbel (ed.), Warszawa 2011.

Kubot Z., Charakter prawny odpowiedzialności porządkowej w Kodeksie pracy [Liability for breach of workplace order, policies or procedures under the Labour Code], Państwo i Prawo 1975, 7.

Marek A., Spory zbiorowe. Część III. Prawo do strajku [Collective disputes. Part III. The right to strike], Służba Pracownicza 2009, 3.

Masewicz W., Kary porzadkowe jako szczególny środek dyscyplinujący [Penalties for breach of workplace order, policies or procedures as a specific disciplinary measure], Państwo i Prawo 1979, 3.

Masewicz W.., Zatarg zbiorowy pracy [Collective dispute], Bydgoszcz 1994.

Patulski W., O pracowniczej odpowiedzialności porządkowej, in: Jedność w różnorodności. Studia z zakresu prawa pracy, zabezpieczenia społecznego i polityki społecznej. Ksiega pamiatkowa dedykowana Profesorowi Wojciechowi Muszalskiemu, Warszawa 2009.

Piątkowski J., Prawo stosunku pracy w teorii i praktyce [Employment relationship law in theory and in practice], Torun 2006.

Piątkowski J., Uprawnienia zakładowej organizacji związkowej [Rights of a company trade union organisation], Toruń 2014.

Sadowski M., Wybrane zagadnienia pracowniczej odpowiedzialności materialnej i osobistej [Selected issues relating to financial and personal liability of an employee], Studia z Zakresu Prawa Pracy i Polityki Społecznej, A. Świątkowski (ed.), Kraków 1994, 71.

Sadurski W., Teoria sprawiedliwości. Podstawowe zagadnienia [A theory of justice. Basic concepts], Warszawa 1988.

Sanetra W., Wina jako przyczyna niezwłocznego rozwiązania umowy o pracę przez zakład pracy [Fault as a cause of immediate termination of a contract of employment by the employer], Ruch Prawniczy, Ekonomiczny i Socjologiczny 1972, 2.

Sanetra W., Odpowiedzialność według prawa pracy. Pojęcie, zakres, dyferencja [Liability under labour law. The concept, the scope, the differentiation], Wrocław 1991.

Sobczyk A., Rozwiąanie umowy o prace bez wypowiedzenia [Termination of a contract of employment without notice], Gdańsk 2010.

Wagner B., Odpowiedzialność za zorganizowanie i udział w nielegalnym strajku [Liability for organising of and participation in an illegal strike], Praca i Zabezpieczenie Społeczne 1992, 1.

Wagner B., in: Kodeks pracy. Komentarz [The Labour Code. Commentary], B. Wagner (ed.), Gdańsk 2010.

Wąż P., in: Komentarz do Kodeksu pracy [A commentary on the Labour Code], K. Walczak (ed.), Warszawa 2012. 
Wojcieszke A., Katalog dóbr osobistych w świetle przepisów konstytucji i kodeksu cywilnego [A catalogue of personal rights in the light of the provisions of the Constitution and the Civil Code], Gdańskie Studia Prawnicze 2000, 7.

Wypych-Żywicka A., Zasadność wypowiedzenia umowy o prace [Legitimate termination of a contract of employment], Gdańsk 1996.

Wypych-Żywicka A., Klauzule określające przesłanki dopuszczalności rozwiązania umów o prace [Clauses laying down the conditions for termination of contracts of employment], in: Studia z Zakresu Prawa Pracy i Polityki Społecznej. Liber Amicorum prof. dr hab. Andrzej Marian Świątkowski, L. Mitrus (ed.), Kraków 2009. 